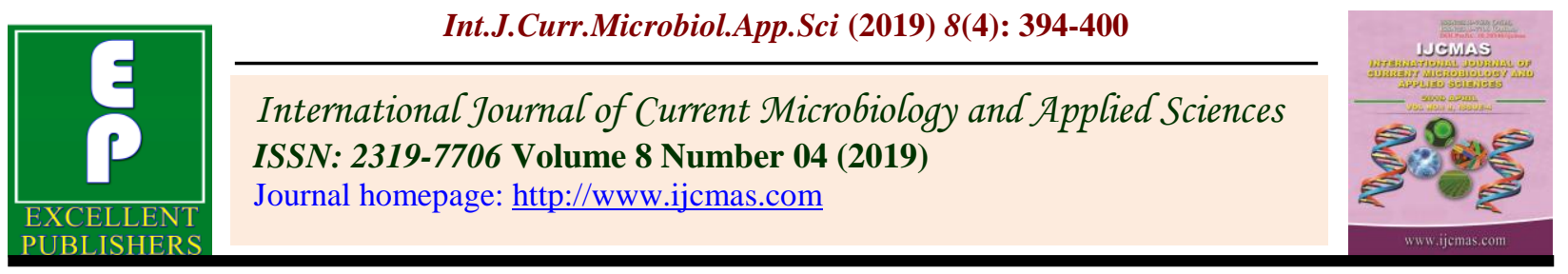

Original Research Article

https://doi.org/10.20546/ijcmas.2019.804.043

\title{
Parent Child Relationship of Rural Mothers and Father with their Young Children in Agrarian Families
}

\author{
Kavitha Kiran*, K. Yashoda and Nasreen Banu \\ All India Coordinated Research Project - Home Science) Human Development Component, \\ PGRC, PJTSAU, Rajendranagar, Hyderabad-30, India \\ *Corresponding author
}

A B S T R A C T

\begin{tabular}{|c|c|}
\hline Keywords & \\
\hline $\begin{array}{l}\text { Parent Child } \\
\text { relationship, } \\
\text { Agrarian families }\end{array}$ & \multirow{3}{*}{$\begin{array}{l}\text { The objective was to understand the Parent Child Relationship of rural mothers and father } \\
\text { with their young children. A sample consisted of } 300 \text { mothers and } 300 \text { fathers of young } \\
\text { children selected randomly. The tools for the present study includes semi structured } \\
\text { interview schedule for collecting demographic profile. Child parent relationship was } \\
\text { studied using Child-Parent Relationship Scale by AICRP-CD. Results concluded that } \\
\text { Parent Child Relationship of rural mothers and father with their young children was good. } \\
\text { Education of parent, facilities, Agricultural land and Housing land available contributed } \\
\text { significantly to the relationship of parent child. }\end{array}$} \\
\hline Article Info & \\
\hline $\begin{array}{l}\text { Accepted: } \\
\text { 04 March } 2019 \\
\text { Available Online: } \\
10 \text { April } 2019\end{array}$ & \\
\hline
\end{tabular}

\section{Introduction}

Parent child relationship includes behavior, feelings, expectation that are unique to a particular parent and a particular child of the many relationship across the life span, relationship between parent and child is more important. According to Sigmund Freud adult development was largely defined by the relationships that children share with their parents. In Psychosocial theory of development, Erikson proposes that infants will grow into trusting adults if their basic needs are satisfied by caregiver, but if care giver fails to satisfy needs are not met will develop feelings of mistrust in future relationships. Lev Vygotsky viewed parents as masters and the child as an apprentice in learning. Albert Bandura's social learning theory likened parents to models who demonstrate behavior that children then copy. Parental behavior during a child's first 5 years of life is critical for the development of important social and cognitive outcomes in children. The child's first relationships, it is now clear, are critical for the establishment of competences-cognitive, social-emotional, and self-regulatory skills - that set the stage for lifelong adaptation and functioning. The interactions and experiences that children have in the home and family setting provide a framework for how the child will interpret his 
or her world and give meaning to culturally framed events.

\section{Operational definition}

\section{Parent child relationship}

The parent-child relationship consists of a combination of behaviors, feelings, and expectations that are unique to a particular parent and a particular child. The relationship involves the full extent of a child's development.

\section{Agrarian families}

Families involved in Agriculture for their livelihood

\section{Research problem}

To assess the influence of demographic factors on parent child relationship of rural mothers and fathers with their young children

\section{Materials and Methods}

The present study was conducted in 4 villages namely Dubbacharla, Kollapadkal, Subhanpur \& Pendyala, of Maheshwarammandal.

A sample consisted of 300 mothers and 300 fathers of young children selected randomly. The tools for the present study includes semi structured interview schedule for collecting demographic profile. Child parent relationship was studied using Child-Parent Relationship Scale by Robert C. Pianta.

\section{Demographic profile of the villages}

There were 250 households in Pendyala village. The total population is 1058 , out of which 532 were males and 1058 were females.
There were 342 households in Dobbacharla village. The total population is 1320 , out of which 708 were males and 612 were females.

There were 356 households in Kalvakolu village. The total population is 1393 , out of which 725 were males and 678 were females.

There were 348 households in Subhanpura village. The total population is 1355 , out of which 761 were males and 694 were females.

There were 342 households in Kollapadkal village. The total population is 1358 , out of which 716 were males and 642 were females.

\section{Results and Discussion}

\section{Socio economic status of the rural family}

With regard to Socio-economic status, out of the 300 sample (rural couples), 215 (72\%) were in lower middle class, 70 (23\%) couple were in upper middle class, and only $15(5 \%)$ were poor (Table 1).

Stage and age wise distribution of rural mothers with young children

With regard to age, out of 300 mothers, 214 $(5 \%)$ were in the age group of 20-25 yrs, 66 $(22 \%)$ were in the age group of 26-30 yrs and $14(5 \%)$ were in the age group of 16-19 yrs (Table 2).

Stage and education wise distribution of Rural mothers with young children

With regard to education, out of 300 mothers, $118(39 \%)$ completed primary education, 84 (28\%) completed secondary education, $50(17 \%)$ completed inter, 32(11\%) were illiterates and $16(5 \%)$ completed graduation (Table 3). 
Stage and occupation wise distribution of Rural mothers with young children

With regard to occupation, out of 300 mothers, 128 (42\%) were fully involved in agricultural activities, 114 (38\%) were partially involved in agricultural activities, 50 $(42 \%)$ were housewives, and $8(3 \%)$ were involved in petit business (Table 4).

Stage and age wise distribution of rural fathers with young children

With regard to age, out of 300 fathers, 128 $(43 \%)$ were in the age group of 26-30yrs, 110 $(37 \%)$ were in the age group of 31-35yrs, 42 $(14 \%)$ were in the age group of $36-40$ yrs and $20(6 \%)$ were in the age group of $20-25 \mathrm{yrs}$ (Table 5).

Stage and education wise distribution of rural fathers with young children

With regard to education, out of 300 fathers, 144 (48\%) completed secondary education, 60 (20\%) completed inter, 50(17\%) completed primary education, 28 (10\%) completed graduation and $18(6 \%)$ were illiterates (Table 6).

Stage and occupation wise distribution of rural fathers with young children

With regard to occupation, out of 300 fathers, $252(84 \%)$ were fully involved in agricultural activities, 18 (6\%) were partially involved in agricultural activities, \& were involved in petit business and 12 (4\%) were in PVT sector (Table 7).

Parent -child relationship scores of rural mothers with young children

With regard to Parent -child relationship scores, out of 300 mothers, $69 \%$ had good relationship and only $31 \%$ had moderate relationship with their children (Table 8).

Parent -child relationship scores of rural fathers with young children

With regard to Parent -child relationship scores, out of 300 fathers, 59\% had good relationship, 34\% had moderate relationship and only $7 \%$ had poor relationship with their children (Table 9).

Influence of demographic factors on parent child relationship of rural mothers and father with their young children

This table 10 provides the $R$ and $R^{2}$ values. The $R$ value represents the simple correlation and is 0.513 which indicates a high degree of correlation. The $R^{2}$ value indicates how much of the total variation in the dependent variable, Parent child relationship, can be explained by the independent variable, Demographic factors. In this case, $26 \%$ can be explained, which is large.

Table.1 Socio economic status of the rural family ( $\mathrm{N}=300$ couples)

\begin{tabular}{|l|l|l|}
\hline SES classification & Score & No \& \% \\
\hline Upper High & $>76$ & - \\
\hline High & $61-75$ & - \\
\hline Upper middle & $46-60$ & $70(23 \%)$ \\
\hline Lower middle & $31-45$ & $215(72 \%)$ \\
\hline Poor & $16-30$ & $15(5 \%)$ \\
\hline Very poor & $<15$ & - \\
\hline
\end{tabular}


Table.2 Stage \& age wise distribution of Rural mothers with young children $(\mathrm{N}=300)$

\begin{tabular}{|c|c|c|c|c|c|}
\hline Sample & Total & $\begin{array}{l}16-19 \text { yrs } \\
\text { N \& \% }\end{array}$ & $\begin{array}{l}20-25 y r s \\
N \& \%\end{array}$ & $\begin{array}{l}26-30 \text { yrs } \\
\text { N \& \% }\end{array}$ & $\begin{array}{l}\text { 31-35 yrs } \\
\text { N\& \% }\end{array}$ \\
\hline $\begin{array}{l}\text { Rural mothers with children } \\
\text { below two years }\end{array}$ & 150 & $14(9 \%)$ & $112(75 \%)$ & $24(16 \%)$ & ---- \\
\hline $\begin{array}{l}\text { Rural mothers with children } \\
\text { between } 2-5 \text { years }\end{array}$ & 150 & --- & $102(68 \%)$ & $42(28 \%)$ & $6(4 \%)$ \\
\hline Total & 300 & $14(5 \%)$ & $214(71 \%)$ & $66(22 \%)$ & $6(2 \%)$ \\
\hline
\end{tabular}

Table.3 Stage \& Education wise distribution of Rural mothers with young children (N=300)

\begin{tabular}{|l|l|l|l|l|l|l|}
\hline Stage & Total & $\begin{array}{l}\text { Illiterate } \\
\text { N \& \% }\end{array}$ & $\begin{array}{l}\text { Primary } \\
\text { school } \\
\text { N \& \% }\end{array}$ & $\begin{array}{l}\text { Secondary } \\
\text { school N \& } \\
\text { \% }\end{array}$ & $\begin{array}{l}\text { Inter } \\
\text { N \& \% }\end{array}$ & $\begin{array}{l}\text { Degree } \\
\text { N \& \% }\end{array}$ \\
\hline $\begin{array}{l}\text { Rural mothers with } \\
\text { children below two yrs }\end{array}$ & 150 & $12(8 \%)$ & $50(33 \%)$ & $44(29 \%)$ & $\begin{array}{l}34 \\
(23 \%)\end{array}$ & $\begin{array}{l}10 \\
(7 \%)\end{array}$ \\
\hline $\begin{array}{l}\text { Rural mothers with } \\
\text { children between 2-5 } \\
\text { yrs }\end{array}$ & 150 & $20(13 \%)$ & $68(45 \%)$ & $40(27 \%)$ & $\begin{array}{l}16 \\
(11 \%)\end{array}$ & $6(4 \%)$ \\
\hline Total & 300 & $32(11 \%)$ & $118(39 \%)$ & $84(28 \%)$ & $\begin{array}{l}50 \\
(17 \%)\end{array}$ & $\begin{array}{l}16 \\
(5 \%)\end{array}$ \\
\hline
\end{tabular}

Table.4 Stage \& Occupation wise distribution of Rural mothers with young children $(\mathrm{N}=300)$

\begin{tabular}{|l|l|l|l|l|l|}
\hline Stage & Total & $\begin{array}{l}\text { House } \\
\text { wife } \\
\text { N \& \% }\end{array}$ & $\begin{array}{l}\text { Fully } \\
\text { involved in } \\
\text { agriculture } \\
\text { N \& \% }\end{array}$ & $\begin{array}{l}\text { Partially } \\
\text { involved } \\
\text { agriculture } \\
\text { N \& \% }\end{array}$ & $\begin{array}{l}\text { Petit } \\
\text { business } \\
\text { N \& \% }\end{array}$ \\
\hline $\begin{array}{l}\text { Rural mothers with } \\
\text { children below two yrs }\end{array}$ & 150 & $22(14 \%)$ & $84(56 \%)$ & $40(27 \%)$ & $4(3 \%)$ \\
\hline $\begin{array}{l}\text { Rural mothers with } \\
\text { children between 2 - 5 } \\
\text { yrs }\end{array}$ & 150 & $28(19 \%)$ & $44(29 \%)$ & $74(49 \%)$ & $4(3 \%)$ \\
\hline Total & 300 & $50(17 \%)$ & $128(43 \%)$ & $114(38 \%)$ & $8(2 \%)$ \\
\hline
\end{tabular}

Table.5 Stage \& age wise distribution of Rural fathers with young children $(\mathrm{N}=300)$

\begin{tabular}{|l|l|l|l|l|l|}
\hline Stage & Total & $\begin{array}{l}\mathbf{2 0}-\mathbf{2 5 y r s} \\
\mathbf{N} \& \%\end{array}$ & $\begin{array}{l}\mathbf{2 6}-\mathbf{3 0} \text { yrs } \\
\mathbf{N} \& \text { \% }\end{array}$ & $\begin{array}{l}\mathbf{3 1}-\mathbf{3 5} \text { yrs } \\
\mathbf{N} \& \%\end{array}$ & $\begin{array}{l}\mathbf{3 6 - 4 0} \text { yrs } \\
\mathbf{N} \& \text { \% }\end{array}$ \\
\hline $\begin{array}{l}\text { Fathers with children } \\
\text { below two yrs }\end{array}$ & 150 & $20(13 \%)$ & $60(40 \%)$ & $52(35 \%)$ & $18(12 \%)$ \\
\hline $\begin{array}{l}\text { Fathers with children } \\
\text { between 2-5 yrs }\end{array}$ & 150 & ---- & $68(45 \%)$ & $58(39 \%)$ & $24(16 \%)$ \\
\hline Total & 300 & $20(6 \%)$ & $128(43 \%)$ & $110(37 \%)$ & $42(14 \%)$ \\
\hline
\end{tabular}


Table.6 Stage \& Education wise distribution of Rural fathers with young children (N=300)

\begin{tabular}{|l|l|l|l|l|l|l|}
\hline Stage & Total & $\begin{array}{l}\text { Illiterate } \\
\text { N \& \% }\end{array}$ & $\begin{array}{l}\text { Primary } \\
\text { school N \& } \\
\text { \% }\end{array}$ & $\begin{array}{l}\text { Secondary } \\
\text { school N \& \% }\end{array}$ & $\begin{array}{l}\text { Inter } \\
\text { N \& \% }\end{array}$ & $\begin{array}{l}\text { Degree } \\
\text { N \& \% }\end{array}$ \\
\hline $\begin{array}{l}\text { Fathers with } \\
\text { children below two } \\
\text { yrs }\end{array}$ & 75 & $12(8 \%)$ & $20(13 \%)$ & $74(49 \%)$ & $30(20 \%)$ & $14(9 \%)$ \\
\hline $\begin{array}{l}\text { Fathers with } \\
\text { children between 2 } \\
-\mathbf{5} \text { yrs }\end{array}$ & 75 & $6(4 \%)$ & $30(20 \%)$ & $70(47 \%)$ & $30(20 \%)$ & $14(9 \%)$ \\
\hline Total & 150 & $18(6 \%)$ & $50(17 \%)$ & $144(48 \%)$ & $60(20 \%)$ & $28(9 \%)$ \\
\hline
\end{tabular}

Table.7 Stage \& Occupation wise distribution of Rural fathers with young children $(\mathrm{N}=300)$

\begin{tabular}{|l|l|l|l|l|l|}
\hline Stage & Total & $\begin{array}{l}\text { Fully involved } \\
\text { in agriculture } \\
\text { N \& \% }\end{array}$ & $\begin{array}{l}\text { Partially } \\
\text { involved } \\
\text { agriculture } \\
\text { N \& \% }\end{array}$ & $\begin{array}{l}\text { Petit } \\
\text { business } \\
\text { N \& \% }\end{array}$ & $\begin{array}{l}\text { Pvt sector } \\
\text { N \& \% }\end{array}$ \\
\hline $\begin{array}{l}\text { Fathers with children } \\
\text { below two yrs }\end{array}$ & 150 & $120(80 \%)$ & $12(8 \%)$ & $10(7 \%)$ & $8(6 \%)$ \\
\hline $\begin{array}{l}\text { Fathers with children } \\
\text { between 2 - 5 yrs }\end{array}$ & 150 & $132(88 \%)$ & $6(4 \%)$ & $8(6 \%)$ & $4(3 \%)$ \\
\hline Total & 300 & $252(84 \%)$ & $18(6 \%)$ & $18(6 \%)$ & $12(4 \%)$ \\
\hline
\end{tabular}

Table.8 Parent -child relationship scores of Rural mothers with young children (N=300)

\begin{tabular}{|l|l|l|l|l|}
\hline Stage & Total & $\begin{array}{l}\text { Poor (<25) } \\
\text { N \& \% }\end{array}$ & $\begin{array}{l}\text { Moderate } \\
\mathbf{( 2 6 - 5 0 )} \\
\mathbf{N} \& \text { \% }\end{array}$ & $\begin{array}{l}\text { Good (51-75) } \\
\text { N \& \% }\end{array}$ \\
\hline $\begin{array}{l}\text { Mothers with children below } \\
\text { two years }\end{array}$ & 150 & ---- & $38(25 \%)$ & $112(75 \%)$ \\
\hline $\begin{array}{l}\text { Mothers with children between } \\
\mathbf{2 - 5} \text { years }\end{array}$ & 150 & ---- & $54(36 \%)$ & $96(64 \%)$ \\
\hline Total & 300 & ---- & $92(31 \%)$ & $208(69 \%)$ \\
\hline
\end{tabular}

Table.9 Parent -child relationship scores of Rural fathers with young children $(\mathrm{N}=300)$

\begin{tabular}{|l|l|l|l|l|}
\hline Stage & Total & $\begin{array}{l}\text { Poor }(<25) \\
\text { N \& \% }\end{array}$ & $\begin{array}{l}\text { Moderate } \\
(\mathbf{2 6 - 5 0 )} \mathbf{N} \& \text { \% }\end{array}$ & $\begin{array}{l}\text { Good (51-75) } \\
\text { N \& \% }\end{array}$ \\
\hline $\begin{array}{l}\text { Fathers with children below two } \\
\text { years }\end{array}$ & 150 & $12(8 \%)$ & $53(35 \%)$ & $85(57 \%)$ \\
\hline $\begin{array}{l}\text { Fathers with children between 2 } \\
-\mathbf{5} \text { years }\end{array}$ & 150 & $8(5 \%)$ & $49(33 \%)$ & $93(62 \%)$ \\
\hline Total & 300 & $20(7 \%)$ & $102(34 \%)$ & $178(59 \%)$ \\
\hline
\end{tabular}


Table.10 Influence of demographic factors on parent child relationship of rural mothers and father with their young children

\begin{tabular}{|l|l|l|l|l|}
\hline Model & R & R Square & Adjusted R Square & $\begin{array}{l}\text { Std. Error of the } \\
\text { Estimate }\end{array}$ \\
\hline 1 & $.513^{\mathrm{a}}$ & .263 & .229 & 8.05505 \\
\hline
\end{tabular}

Table.11 ANOVA

\begin{tabular}{|l|l|l|l|l|l|l|}
\hline \multicolumn{2}{|l|}{ ANOVA } & \multicolumn{3}{l|}{ Sig. } \\
\hline Model & $\begin{array}{l}\text { Sum } \\
\text { Squares }\end{array}$ & of & df & Mean Square & F & \\
\hline \multirow{2}{*}{1} & Regression & 6616.355 & 13 & 508.950 & 7.844 & $.000^{\text {b }}$ \\
\cline { 2 - 8 } & Residual & 18556.765 & 286 & 64.884 & & \\
\cline { 2 - 8 } & Total & 25173.120 & 299 & & \\
\hline
\end{tabular}

Table.12 Coefficients predicting Parent child relationship

\begin{tabular}{|c|c|c|c|c|c|}
\hline Unst & ndardiz & efficients & Standardize & $\mathrm{t}$ & Sig. \\
\hline & & Std. Error & Beta & & \\
\hline Age & .056 & .098 & .029 & .575 & .566 \\
\hline Income & 1.480 & 1.576 & .167 & .939 & .349 \\
\hline Education & 3.901 & 2.123 & .214 & 1.837 & $.05 *$ \\
\hline Occupation & 2.386 & 2.074 & .198 & 1.150 & .251 \\
\hline $\begin{array}{l}\text { Family } \\
\text { possessions }\end{array}$ & .273 & .834 & .045 & .328 & .743 \\
\hline Type of house & .034 & .758 & .005 & .045 & .964 \\
\hline $\begin{array}{l}\text { No. earning } \\
\text { members }\end{array}$ & 2.301 & 1.383 & .124 & 1.664 & .097 \\
\hline No. of children & .966 & .849 & .106 & 1.138 & .256 \\
\hline Facilities & 3.587 & 1.097 & .194 & 3.269 & $.001 *$ \\
\hline $\begin{array}{l}\text { Education of } \\
\text { children }\end{array}$ & 1.277 & 1.156 & .073 & 1.105 & .270 \\
\hline locality & .370 & .897 & .036 & .412 & .681 \\
\hline $\begin{array}{l}\text { Agricultural } \\
\text { land }\end{array}$ & 5.128 & 1.886 & .222 & 2.719 & $.007^{*}$ \\
\hline Housing land & 3.684 & 1.327 & .209 & 2.775 & $.006 *$ \\
\hline
\end{tabular}




\section{ANOVA}

ANOVA table, which reports how well the regression equation fits the data (i.e., predicts the dependent variable). Table 11 indicates that the regression model predicts the dependent variable significantly well. Here, $p<0.000$, which is less than 0.01 , and indicates that, overall, the regression model statistically significantly predicts the outcome variable

\section{Coefficients predicting Parent child relationship}

The regression coefficient table 12 provides significant predictors of parent child relationship. From the table 12 it could be stated that education of parent, facilities, Agricultural land and Housing land available significantly predicted the parent child relationship at 0.011 evel of significance.

The study concludes that Parent Child Relationship of rural mothers and father with their young children as good. Education of parent, facilities, Agricultural land and Housing land available contributed significantly to the relationship of parent child.
Note: The present study was supported by ICAR under XIII plan period

\section{References}

Alvergne, A., Faurie, C., and Raymond, M. (2009). Father- off spring resemblance predicts paternal investment in humans. Animal Behaviors, 78, $61-69$.

Belsky, J. (1984). The determinants of parenting: A process model. Child Development, 55, $83-96$.

Belsky, J. (1997a). Attachment, mating, and parenting: An evolutionary interpretation. Human Nature, 8, 361 381.

Peterson, C. A., Luze, G. J., Eshbaugh, E. M., Jeon, H. J., and Kantz, K. R. (2007). Enhancing parent- child interactions through home visiting: Promising practice or unfulfilled promise? Journal of Early Intervention, 29(2), 119-140.

Sanders, M. R., and Woolley, M. L. (2005). The relationship between maternal self-efficacy and parenting practices: Implications for parent training. Child: Care, Health and Development, 31(1), 65-73.

\section{How to cite this article:}

Kavitha Kiran, K. Yashoda and Nasreen Banu. 2019. Parent Child Relationship of Rural Mothers and Father with their Young Children in Agrarian Families. Int.J.Curr.Microbiol.App.Sci. 8(04): 394-400. doi: https://doi.org/10.20546/ijcmas.2019.804.043 